\title{
Role of feeding strategies in seabird-minke whale associations
}

\author{
Pia Anderwald ${ }^{1,2,3, *}$, Peter G. H. Evans ${ }^{1}$, Lorenz Gygax ${ }^{4}$, A. Rus Hoelzel ${ }^{2}$ \\ ${ }^{1}$ Sea Watch Foundation, Ewyn Y Don, Bull Bay, Amlwch, Anglesey LL68 9SD, UK \\ ${ }^{2}$ School of Biological and Biomedical Sciences, Durham University, South Road, Durham DH1 3LE, UK \\ ${ }^{3}$ Coastal and Marine Research Centre, University College Cork, Irish Naval Base, Haulbowline, Cobh, Co. Cork, Ireland \\ ${ }^{4}$ Centre for Proper Housing of Ruminants and Pigs, FVO, Agroscope Research Station ART, 8356 Ettenhausen, Switzerland
}

\begin{abstract}
Mixed-species foraging groups are well known for a broad range of taxonomic groups. Explanations have focused around 2 primary mechanisms: anti-predator behaviour and maximising foraging efficiency. In the ocean, feeding assemblages can involve seabirds, fish, cetaceans, pinnipeds and combinations of these groups. Here we examine association patterns between North Atlantic minke whales and seabirds. Based on the unique feeding strategies of different seabird guilds, predictions were made on the relationship between seabirds and whales in joint feeding assemblages (who profits from whom). These predictions were tested by modelling the presence of a whale with seabird aggregations using logistic regressions, involving presence/absence of seabird guilds, group sizes and measures of diversity as explanatory variables. A strong positive relationship was found between the presence of a whale with a seabird aggregation and the presence and group size of auks, the only seabird group able to concentrate fish on their own. No other seabird guild was relevant in predicting the presence of a whale. This suggests that 'beater' or 'pirate' theory best explains the relationship, with minke whales taking advantage of prey concentrations generated by the feeding behaviour of auks, and other bird groups taking advantage of dead, stunned or scattered prey left by the whales.
\end{abstract}

KEY WORDS: Species interaction $\cdot$ Balaenoptera acutorostrata $\cdot$ Foraging theory Resale or republication not permitted without written consent of the publisher

\section{INTRODUCTION}

Temporary associations between individuals of different species, families or even classes are widespread among vertebrates both in terrestrial and marine environments. Multi-taxa groups can serve several purposes, from predator defense to improved access to resources (Diamond 1981). In the latter context, several theories have been developed on how individuals may benefit from multi-species feeding groups. According to the feeding efficiency theory, different species or groups of species in an association can take on specific roles according to their different feeding strategies, thus not only reducing interspecific competition but also allowing maximum efficiency in exploiting patchy food resources. The reason is that prey, which are out of reach for one species, can be exploited by another predator in the same group with a different feeding strategy (e.g. Sealy 1973, Camphuysen \& Webb 1999). In the same context, certain species may also take advantage of prey 'leavings' from another species (beater theory) or steal prey already concentrated or identified by another species (pirate theory; Diamond 1981). However, different taxa can simply be attracted to the same resource without further interacting with each other or benefiting from the other species, as might be the case for some temporal associations between cetaceans (Evans 1980, 1982).

Temporary inter-taxa associations between a wide range of seabirds and marine mammals are well documented worldwide and are generally linked to feeding activities (e.g. Harrison 1979, Evans 1982, Duffy 1983, Pierotti 1988a, Harrison et al. 1991, Camphuysen \& Webb 1999, Vaughn et al. 2008, Bearzi et al. 2009). Apart from special cases where seabirds feed directly on cetacean skin (Thomas 1988, Rowntree et al. 1998) 
or from faeces and vomit of cetaceans (Clarke et al. 1981, Clarke \& Prince 1981), such associations appear to be based predominantly on seabirds taking advantage of a temporary food source created by cetaceans (or pinnipeds) trapping live fish or plankton against the surface, or leaving injured or dead prey that can be scavenged (Harrison 1979, Evans 1982, Martin 1986, Pitman \& Ballance 1992, Verheyden 1993, Bräger 1998, Ballance \& Pitman 1999, Bugoni \& Vooren 2004, Vaughn et al. 2008). By contrast, few authors have examined the possibility of marine mammals taking advantage of seabird feeding activity: Pierotti (1988b) provided evidence that humpback whales can use feeding flocks of gulls as visual cues to prey concentrations in the western North Atlantic, while Hoelzel et al. (1989) found that, in the eastern North Pacific, some minke whales specialized in bird association feeding (apparently taking advantage of bait balls herded by auks), whereas others were consistently observed feeding without seabirds associated.

In UK waters, short-term (minutes to hours) associations between minke whales Balaenoptera acutorostrata and several seabird species, most frequently involving common guillemots Uria aalge, razorbills Alca torda, kittiwakes Rissa tridactyla, herring gulls Larus argentatus and Manx shearwaters Puffinus puffinus, are commonly observed (Evans 1982). The relative frequency of these species in feeding groups depends primarily on the distance from breeding colonies. The present study was conducted on the west coast of Scotland between late July and September, representing the period immediately after breeding for guillemots, razorbills, kittiwakes and Larus gulls, during which auks are still distributed close to their colonies with their flightless young (Gaston et al. 1998) whereas Manx shearwater chicks do not normally fledge before September (Brooke 1990). All species share the same diet with minke whales (namely sprat Sprattus sprattus, juvenile herring Clupea harengus and sandeels Ammodytes marinus; Table 1) and exploit prey of similar size. During the study period, both minke whales and seabirds were found to feed predominantly on sprat (Anderwald 2009), a small shoaling species of high calorific content (Hislop et al. 1991) that occurs predominantly in midwater over the continental shelf. After spawning in spring, sprat build up their fat reserves during summer and migrate inshore in July/August, aggregating in overwintering concentrations in coastal waters by October/November, by which time they cease feeding (De Silva 1973, Lee \& Ramster 1981).

In accordance with the feeding efficiency theory (Sealy 1973, Diamond 1981), the different seabird taxa often occur in multi-species feeding flocks, in which each species takes on a specific role (Camphuysen \& Webb 1999; Table 1). Auks (guillemots, razorbills and puffins Fratercula arctica) have been referred to as initiators or producers because of their capability of diving to considerable depths (up to $180 \mathrm{~m}$ in the case of common guillemots; Piatt \& Nettleship 1985) and herding fish against the surface, thus making prey available to other seabirds. Kittiwakes have been characterized as a nuclear species (Sealy 1973) or catalyst (Hoffman et al. 1981) because they are normally the first to join feeding auks, and their bright white plumage makes them particularly conspicuous to other seabirds, even from great distances. By contrast, Larus gulls (herring gull, lesser (Larus fuscus) and greater (Larus marinus) blackbacked gulls) have been identified as joiners and suppressors by Camphuysen \& Webb (1999) because of their tendency to arrive last in feeding aggregations, placing themselves on top of the fish shoal (thus blocking access to it to the smaller kittiwakes), and the observation of groups normally breaking up soon after their arrival (Table 1). The role of Manx shearwaters in these aggregations is less clear: like auks, they can hunt fish underwater (by pursuit plunging rather than pursuit

Table 1. Diet, feeding strategy and role in multi-species feeding aggregations (after Camphuysen \& Webb 1999) of the main seabird species commonly found associated with minke whales in the study area

\begin{tabular}{|c|c|c|c|c|}
\hline Seabird species & $\begin{array}{l}\text { Feeding } \\
\text { strategy }\end{array}$ & Diet & $\begin{array}{l}\text { Role in feeding } \\
\text { groups }\end{array}$ & Source \\
\hline $\begin{array}{l}\text { Auks (common } \\
\text { guillemot } \\
\text { and razorbill) }\end{array}$ & $\begin{array}{l}\text { Pursuit } \\
\text { diving }\end{array}$ & $\begin{array}{l}\text { Herring, sprat, sandeel, } \\
\text { mackerel, capelin }\end{array}$ & Initiators, producers & $\begin{array}{l}\text { Evans (1990), Hatchwell (1991), } \\
\text { Skøv et al. (2000), Davoren \& } \\
\text { Montevecchi (2003) }\end{array}$ \\
\hline $\begin{array}{l}\text { Larus gulls } \\
\text { (herring gull, } \\
\text { greater and lesser } \\
\text { black-backed gull) }\end{array}$ & $\begin{array}{l}\text { Surface } \\
\text { seizing, } \\
\text { shallow } \\
\text { plunging }\end{array}$ & $\begin{array}{l}\text { Herring, sprat, sandeel, } \\
\text { capelin, long-finned } \\
\text { squid; catholic diet, } \\
\text { including offal }\end{array}$ & $\begin{array}{l}\text { Joiners (suppressors, } \\
\text { kleptoparasites) }\end{array}$ & $\begin{array}{l}\text { Pierotti (1988b), P. Anderwald } \\
\text { (pers. obs.) }\end{array}$ \\
\hline Kittiwake & $\begin{array}{l}\text { Shallow } \\
\text { plunging or } \\
\text { dipping }\end{array}$ & $\begin{array}{l}\text { Herring, sprat, sandeel, } \\
\text { mackerel, capelin, } \\
\text { zooplankton }\end{array}$ & Catalyst & $\begin{array}{l}\text { Evans (1990), Wanless \& Harris } \\
\text { (1992), Skøv et al. (2000), } \\
\text { Carscadden et al. (2002) }\end{array}$ \\
\hline Manx shearwater & $\begin{array}{l}\text { Pursuit } \\
\text { plunging }\end{array}$ & $\begin{array}{l}\text { Herring, sprat, sandeel, } \\
\text { sardines, squid }\end{array}$ & $\begin{array}{l}\text { Joiner (suppressor: short- } \\
\text { tailed and sooty shearwaters) }\end{array}$ & $\begin{array}{l}\text { Brooke (1990), Hoffman et al. } \\
\text { (1981) }\end{array}$ \\
\hline
\end{tabular}


diving) and do not depend on direct surface access to the shoal, as do kittiwakes and Larus gulls. However, they do not appear to be able to herd fish themselves or drive them towards the surface in the way that auks do. One reason may be that they appear to attack a fish shoal mainly from above or from the upper sides (P. Anderwald pers. obs.). This feeding strategy would be likely to cause a fish shoal to descend to greater depths if no auks or other predators are present from below at the same time to drive it upwards. Manx shearwaters were also classified as joiners by Camphuysen \& Webb (1999), whereas Hoffman et al. (1981) classified the closely related short-tailed (Puffinus tenuirostris) and sooty (Puffinus griseus) shearwaters as suppressors in feeding flocks observed off Alaska because of their tendency to disperse food sources by group pursuit plunging.

As different taxa are constrained by their morphologies to their own set of characteristic feeding mechanisms, it is likely that each group (or guild) would occupy the same role in association with a whale as in a multi-species feeding aggregation with other birds. Based on the association patterns between minke whales and different seabird taxa, it is thus possible to make the following prediction about the relationship between whales and seabirds: if minke whales predominantly trap fish against the surface and are followed by seabirds taking advantage of this activity, it would be expected that mainly the more mobile species (kittiwakes, Larus gulls and Manx shearwaters with approximately equal frequencies of occurrence) in the study area would be found in association with whales, because they can follow them around more easily than the less mobile auks. However, if minke whales were taking advantage of prey located and herded by seabirds, a closer association between whales and auks would be expected.

While several authors have described inter-taxa feeding assemblages and inferred potential relationships between the different groups in associations between seabirds and marine mammals predominantly from qualitative observational data, we test our hypothesis with a quantitative approach, based on the feeding strategies characteristic for different seabird guilds, and discuss our results in the light of additional behavioural observations.

\section{MATERIALS AND METHODS}

Fieldwork. Fieldwork was conducted around the Small Isles (Eigg, Rhum, Muck and Canna), West Scotland (Fig. 1), for a total of 21 wk during summer months 2003-2007 (4-31 August 2003, 17 August10 September 2004, 24 July-12 September 2005, 2 August-3 September 2006 and 20-29 July 2007) with the aim of following individual minke whales for an examination of diving behaviour with respect to environmental parameters, collecting distributional data on both cetaceans and seabirds, and examining association patterns between the taxa. Water depths within the study area ranged from 20 to 150 m (Fig. 1). Although no standardized line-transect surveys were conducted, the study area was covered as widely as possible in search of whales, with focal follows of individual minke whales conducted as soon as an animal was found. Notes were taken on every encounter with a seabird group or cetacean species. A seabird group was defined as an aggregation of $>10$ individuals of one or more species that was either sitting on the water

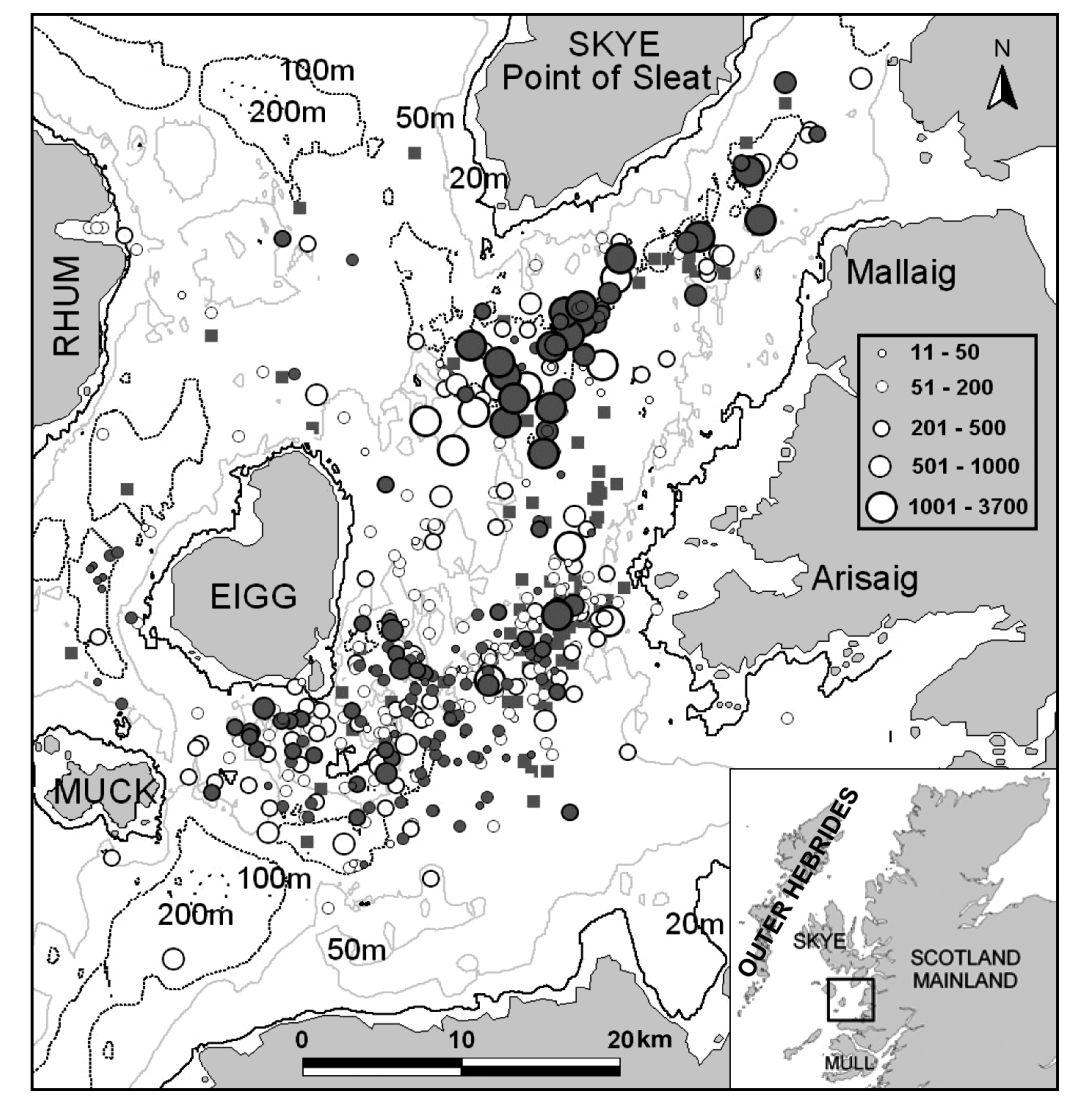

Fig. 1. Seabird aggregations (auks, Larus gulls, kittiwakes and Manx shearwaters) with (dark grey) and without (white) minke whales Balaenoptera acutorostrata associated. Symbol size is proportional to overall group size of bird aggregations which were counted. Squares represent bird groups that were not counted. Inset: location of the study area 
or flying, but showing a clear interest in the water surface (i.e. circling or hovering; transiting birds were ignored), and was clearly separated spatially from other such groups. Larger aggregations could be spread over an area of $2000 \mathrm{~m}^{2}$ or more. Time and position of encounter, species composition and whether a minke whale was associated with the aggregation were all recorded. Where time allowed, the number of individuals of each species was counted. For large groups, individuals of the same species were counted in groups of 10 up to 50 or 100 within a restricted area, and this number was then extrapolated to the total area occupied by the flock, taking into account differences in densities. If there was insufficient time to approach the birds close enough for a direct count (i.e. during a focal follow of a whale), only the presence of each species was recorded. A minke whale was considered associated with a seabird aggregation if it surfaced at a distance of $100 \mathrm{~m}$ or less from the group. Although each seabird group was counted only once, a single minke whale could be associated with more than one group (although not simultaneously), e.g. during the course of a focal follow. A pilot study using the same methodology had already been conducted in the same area between 17 and 23 September 2001 (Anderwald et al. 2002), and data from that week were included in the analysis. Surfacing behaviour and feeding events by minke whales associated with a seabird aggregation were also recorded. However, only the subset of feeding events evident from the surface (i.e. surface lunges) could be detected.

Data analysis. The seabirds most commonly encountered in the study area were divided into 4 functional groups or guilds, depending on their feeding strategies (Table 1): (1) pursuit divers, i.e. auks (common guillemots, razorbills and puffins, but dominated by guillemots); (2) surface seizers, i.e. Larus gulls (herring gulls, greater and lesser black-backed gulls, but dominated by herring gulls); (3) dippers, i.e. kittiwakes; and (4) pursuit plungers, i.e. Manx shearwaters. Other taxa (gannets Morus bassanus, shags Phalacrocorax aristotelis, great Stercorarius skua and arctic Stercorarius parasiticus skuas, common Sterna hirundo and arctic Sterna paradisaea terns, storm petrels Hydrobates pelagicus, sooty shearwaters Puffinus griseus and fulmars Fulmarus glacialis) were encountered too infrequently in aggregations of $>10$ individuals to be included in the analysis.

For each seabird aggregation that had been counted, diversity was expressed as the Simpson's index with respect to the 4 guilds, calculated as: $D=1 /\left(\Sigma P_{i}^{2}\right)$, where $P$ is the proportion of each guild (after Simpson 1949, Begon et al. 1986, p. 682). In addition, the dominant guild was determined for each aggregation, defined as the functional group making up $>50 \%$ of the total number of individuals (aggregations in which no guild fulfilled this criterion were categorized as 'none' with respect to this factor).

In order to assess the relative importance of the quantitative and qualitative composition of a bird aggregation in determining the presence of a minke whale, 3 logistic regressions were performed (Table 2). The 3 models focused on: (1) the quantitative (including group sizes of each guild), (2) the qualitative (including presence/absence of each guild) and (3) the overall composition of seabird aggregations (replacing group sizes of each guild from Model 1 with total group size of the aggregation, which is dependent on the former and could therefore not be included in the same model). Each model used the presence or absence of a minke whale (per seabird group) as the dependent variable. All group sizes were square-roottransformed in order to fulfil the requirement of Poisson-distributed residuals, and the classification cut-off value was adjusted to the relative frequency of aggregations with minke whales present. Model selection was based on a stepwise backward procedure using the likelihood ratio, and the probability threshold for removal of a parameter was set to 0.05. Analyses were conducted in SPSS v.14.

Using the same methodology, the surface-feeding behaviour (surface lunge observed/not observed) of minke whales associated with a seabird aggregation was investigated in a fourth logistic regression, with presence/absence of auks, Larus gulls, kittiwakes and Manx shearwaters, and total number of seabird guilds present as explanatory variables.

Table 2. Explanatory variables included in each logistic regression

\begin{tabular}{|lccc|}
\hline \multirow{2}{*}{ Explanatory variable } & \multicolumn{3}{c}{ Model $\_$} \\
\cline { 2 - 4 } & 1 & 2 & 3 \\
\hline Continuous & & & \\
Simpson's index & $\times$ & & $\times$ \\
Group size of: & & & \\
$\quad$ Total seabird aggregation & & & $\times$ \\
Auks & $\times$ & & \\
Larus gulls & $\times$ & & \\
Kittiwakes & $\times$ & & \\
Manx shearwaters & $\times$ & & \\
Categorical & & & \\
Total number of guilds & & & \\
$\quad(4$ categories) & $\times$ & $\times$ & $\times$ \\
Dominant guild (5 categories) & $\times$ & & $\times$ \\
Presence/absence of: & & & \\
Auks & & $\times$ & \\
Larus gulls & & $\times$ & \\
Kittiwakes & & $\times$ & \\
Manx shearwaters & & $\times$ & \\
\hline
\end{tabular}




\section{RESULTS}

A total of 606 seabird aggregations were encountered between 2001 and 2007 (excluding 2002), of which $438(72 \%)$ could be fully counted. Among the 4 guilds, Manx shearwaters dominated with respect to the overall number of individuals, but auks were present in feeding aggregations most frequently (Table 3). A moderate negative correlation $(r=-0.604)$ was detected between numbers of Larus gulls and Manx shearwaters, whereas correlations between numbers of individuals for all other pairs of guilds were weak $(0.316<|r|<0.485)$. Because of the large sample sizes, all correlations were significant ( $p<0.001)$, but as no strong co-linearity was detected, group sizes of all guilds could be included in the same model. The same applied when only presence/absence of guilds were taken into consideration (Russell and Rao measure $\leq 0.442$ ). Seabird aggregations were distributed throughout the study area, but the largest groups were confined to the area around the entrance to the Sound of Sleat between the north end of the Isle of Eigg and Mallaig on the west mainland coast, and between Eigg and Arisaig (Fig. 1).

Minke whales were associated with $39.5 \%$ of the 438 seabird aggregations that could be fully counted. There was no obvious spatial segregation between bird groups with or without minke whales present (Fig. 1). The presence or group size of auks in seabird aggregations were the most important variables in determining whether a minke whale was associated with birds: the likelihood of a minke whale being present with a seabird aggregation increased slightly but significantly with the number of auks present (Model 1: global p <0.001, $B=0.094$, odds ratio $=1.099,95 \%$ CI: lower $=1.054$, upper $=$ 1.146; Fig. 2), although this variable only explained a small percentage of the total variance (Nagelkerke $\mathrm{R}^{2}=0.069$ ). All other variables initially included in the model were non-significant (Figs. 2 to 4). This

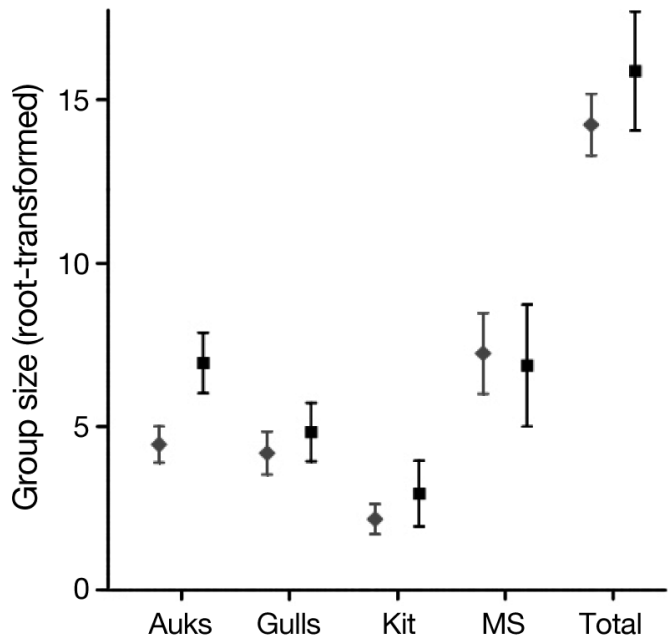

Fig. 2. Group sizes (mean $\pm 95 \% \mathrm{CI}$ ) of the 4 seabird guilds (auks, Larus gulls, kittiwakes and Manx shearwaters) and total size of seabird aggregations in the presence ( $\square$ ) and absence $(\star)$ of minke whales Balaenoptera acutorostrata ( $\mathrm{n}=438$ seabird aggregations). Kit: kittiwakes, MS: Manx shearwaters

Table 3. Descriptive statistics for seabird aggregations, divided into the 4 guilds. The median group size refers only to those groups where the guild was present. CGL: common guillemot, GBB: greater black-backed gull, HG: herring gull, LBB: lesser black-backed gull, PUF: puffin, RAZ: razorbill

\begin{tabular}{|c|c|c|c|c|c|c|}
\hline \multirow[t]{2}{*}{ Guild } & \multicolumn{2}{|c|}{ Groups -} & \multicolumn{2}{|c|}{ - Individuals -} & \multicolumn{2}{|c|}{ — Group size - } \\
\hline & No. & $\%$ & Total no. & $\%$ & Max. & Median \\
\hline Auks (68.5\% CGL, 31.4\% RAZ, $0.1 \%$ PUF) & 492 & 81.2 & 25800 & 18.6 & 2000 & 30 \\
\hline Larus gulls (95.2\% HG, $4.6 \%$ GBB, $0.2 \%$ LBB) & 281 & 46.4 & 22600 & 16.3 & 1100 & 73 \\
\hline Kittiwakes & 248 & 40.9 & 14200 & 10.3 & 3000 & 25 \\
\hline Manx shearwaters & 304 & 50.2 & 76100 & 54.9 & 3500 & 140 \\
\hline Total & 606 & & 138800 & & 3700 & 157 \\
\hline
\end{tabular}




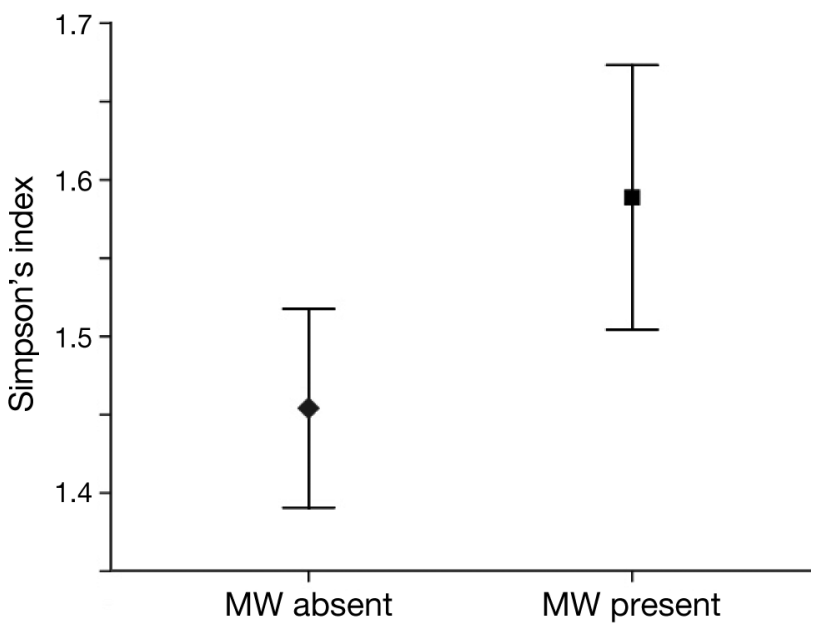

Fig. 4. Simpson's index (mean $\pm 95 \% \mathrm{CI}$ ) with respect to the 4 guilds (auks, Larus gulls, kittiwakes and Manx shearwaters) for seabird aggregations with minke whales (MW) absent and present, respectively; $\mathrm{n}=438$ seabird aggregations

result remained the same when the model was reduced to presence/absence of functional bird groups and overall number of guilds present; only the presence of auks remained significant (Fig. 5) and was included in the final model (Model 2: global p < $0.001, B=1.012$, odds ratio $=2.751,95 \% \mathrm{CI}$ : lower $=$ 1.768, upper $=4.279$; Nagelkerke $R^{2}=0.047$ ), whereas the presence of all other guilds, as well as the number of groups present (Fig. 3b), were insignificant.
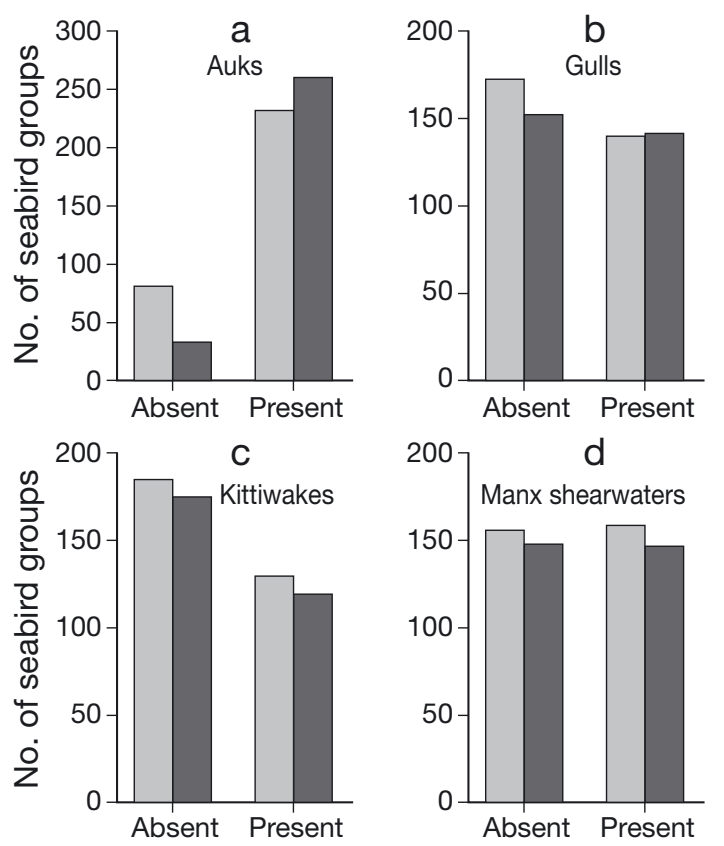

Fig. 5. Numbers of seabird aggregations with minke whales present/absent against presence/absence of each of the 4 guilds (auks, Larus gulls, kittiwakes and Manx shearwaters). Ligh grey bars: minke whale absent, dark grey bars: minke whale present
However, if individual guilds were not included in the model, but only the total number of individuals in the aggregation, the overall group size, Simpson's index and dominant guild were all necessary to explain the presence of minke whales (Model 3: global $\mathrm{p}=0.001$, Nagelkerke $\mathrm{R}^{2}=0.08$; Figs. 2 to 4 ). A whale was more likely to be associated with larger seabird aggregations $(B=0.028, \mathrm{p}=0.011$, odds ratio $=1.028$, $95 \% \mathrm{CI}$ : lower $=1.006$, upper $=1.051$ ) with high diversity (Simpson's index: $B=0.546, \mathrm{p}=0.036$, odds ratio $=$ $1.726,95 \% \mathrm{CI}$ : lower $=1.035$, upper $=2.878$ ) and if the group was dominated by auks (dominant group: $\mathrm{p}=$ $0.003 ; B_{\text {auks }}=1.067, \mathrm{p}=0.031$, odds ratio $=2.908,95 \%$ CI: lower $=1.102$, upper $=7.675$ ).

The likelihood of observing minke whales surfacefeeding was significantly higher in the presence of kittiwakes and large gulls, i.e. the 2 taxa which depend on prey close to the surface (for both: $B=0.729$, $\mathrm{p}=0.014$, odds ratio $=2.072,95 \% \mathrm{CI}$ : lower $=1.162$, upper = 3.696; global $\mathrm{p}<0.001$, Nagelkerke $\mathrm{R}^{2}=$ 0.104 ), but was independent of the presence of auks and Manx shearwaters or the number of guilds present (Figs. $6 \& 7$ ).
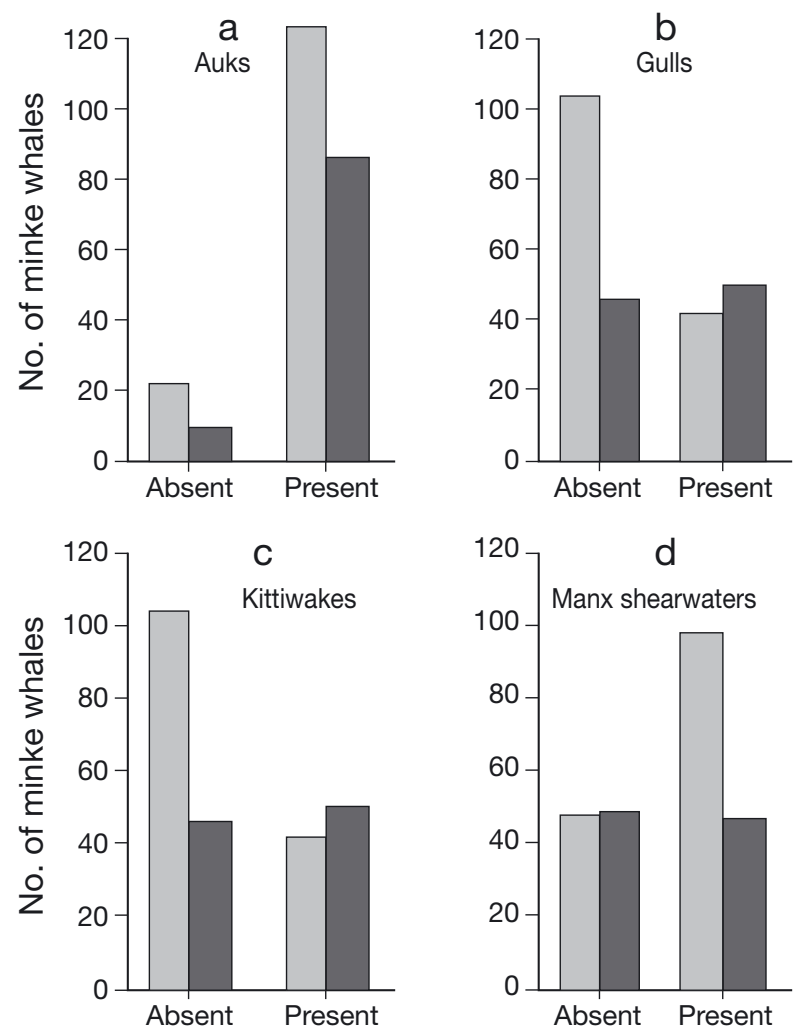

Fig. 6. Surface-feeding activity of minke whales Balaenoptera acutorostrata in relation to the presence/absence of the 4 seabird guilds (auks, Larus gulls, kittiwakes and Manx shearwaters). Light grey bars: no surface feeding observed $(n=146)$, dark grey bars: surface feeding observed $(n=96)$ 


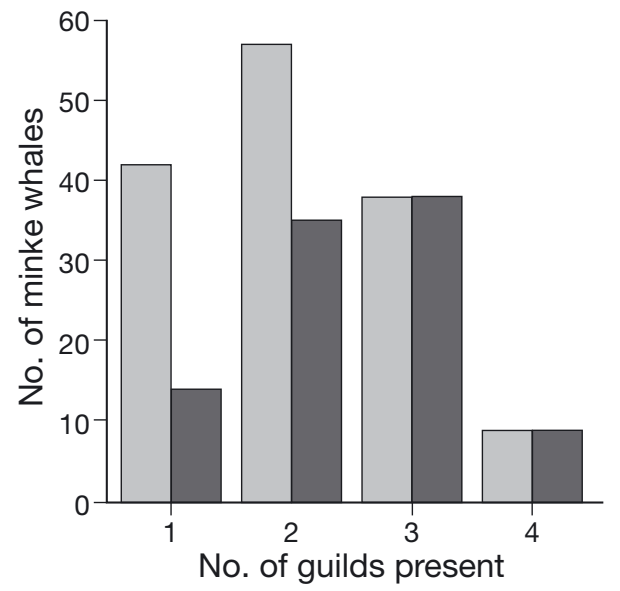

Fig. 7. Observations of surface-feeding activity by minke whales Balaenoptera acutorostrata in relation to the number of seabird guilds (auks, Larus gulls, kittiwakes and Manx shearwaters) present. Light grey bars: no surface feeding observed, dark grey bars: surface feeding observed

\section{DISCUSSION}

In most cases of cetacean-seabird interactions investigated to date, seabirds appear to take advantage of the fact that cetaceans make prey available near the surface (Harrison 1979, Evans 1982, Martin 1986, Pitman \& Ballance 1992, Verheyden 1993, Bräger 1998, Camphuysen \& Webb 1999, Vaughn et al. 2008). However, both Pierotti (1988b) and Hoelzel et al. (1989) described examples in which baleen whales can profit from the feeding activities of seabirds.

The positive relationship between the overall size and diversity of a seabird aggregation with the presence of a minke whale found in the third logistic regression model is intuitive, as a larger fish shoal near the surface is expected to attract both whales and a large number and variety of birds. This does not allow any inference about the relationship between whales and seabirds, other than that both are feeding on the same prey. In the present analysis, however, a close association between minke whales and auks was detected for 3 different logistic regressions. A minke whale was more likely to be associated with a bird aggregation when auks were present (Model 2), when auk numbers were high (Model 1) and when they represented the dominant guild within the aggregation (Model 3). In the first 2 analyses, numbers and presence of auks, respectively, were the only significant parameters left in the final models. These results can be interpreted as either a particularly close link between minke whales and auks with respect to diet, or a real interaction.

Although the overlap in diet between minke whales and auks appears strong, this also applies to kittiwakes (Table 1). In order to determine whether the close relationship between whales and auks represents a real interaction, it is important to know who tends to arrive at fish shoals first. The other 3 seabird guilds-Larus gulls, kittiwakes and Manx shearwaters-are very mobile and can follow each other or (potentially) minke whales in search of food. Auks, however, tend to be more stationary, often sitting on the water in rafts. On the basis of this behaviour, their foraging strategy may involve waiting in potentially productive locations until the foraging conditions become more favourable. Because no feeding hotspots could be identified in particular locations within the study area (see Fig. 1), waiting and searching strategies may yield similar payoffs. Minke whales appear to adjust their foraging activity according to the tidal currents (Anderwald 2009). The implication is that whales move around the study area to locations with comparatively strong currents at any state of the tidal cycle, i.e. covering a large area and thus increasing their chances of finding prey. The low energetic cost of swimming for a minke whale (Blix \& Folkow 1995), and a gull's ability to combine soaring and flapping flight to control energetic cost (ShamounBaranes \& van Loon 2006), would facilitate this strategy. However, it is likely to be less rewarding for auks, which expend more energy during flight than other seabirds because of their short, narrow-winged, lowendurance wing design with heavy wing-loading in proportion to their body weight (Gaston 2004, p. 51-57). Waiting in prospective productive locations would therefore be energetically beneficial to auks, yielding fewer but potentially more reliable feeding opportunities than for whales and the other seabird taxa. Although small groups of auks did sometimes join in on already actively feeding seabird aggregations, they were never observed joining minke whales or potentially following them. Combined with the fact that the feeding strategy of guillemots allows them to drive fish towards the surface themselves, it is therefore more likely that minke whales joined auks on feeding locations rather than vice versa, and that it was mainly the case that whales were utilizing resources that the auks (and other seabirds which had arrived before the whale) were already feeding on. This conclusion was also reached independently from observations during focal follows of minke whales conducted in parallel to the present study: the surfacing location of a focal whale previously not associated with birds could often be predicted to occur in the direction of an actively feeding seabird aggregation that had formed at some distance, before the animal would lunge in the centre of the group. Because every surfacing position of the focal animal was known and the boat was kept close to it, the focal whale could not have been involved in herding the fish shoal towards the surface.

Although the strong association between minke whales and auks in feeding aggregations suggests that 
minke whales do exploit prey patches already herded by auks when they happen to become available in the whales' vicinity, auks and whales appeared to behave largely independently of each other, and there was no indication that minke whales were concentrated in locations where auks were present. Surface-feeding by minke whales also occurred in the absence of auks, with only gulls, kittiwakes or Manx shearwaters present. The whales do therefore corral fish independently in this area when needed, although taking advantage of fish already herded by auks is likely to be a more energy-efficient and thus preferable feeding strategy for the animals when these opportunities are available.

Where resources are patchy and unpredictable, it should be advantageous to individuals to be opportunistic. In the same way that minke whales sometimes may profit from the feeding activities of auks, but otherwise herd fish on their own, the Larus gulls, kittiwakes and especially single-species flocks of Manx shearwaters likely joined both auks and minke whales, if the latter were driving fish towards the surface. The fact that these 3 seabird guilds were not good predictors of the presence of a whale is further indication that joining foraging minke whales represents only one of many strategies for these groups for finding food. Kittiwakes and Larus gulls were also frequently observed accompanying fishing vessels. Other 'natural' feeding opportunities for all seabirds, including auks, may have involved harbour porpoises (Phocoena phocoena), seals or predatory fish such as mackerel (Scomber scombrus) driving fish shoals close to the surface. Harbour porpoises were observed in association with $93(15.3 \%)$ seabird aggregations, and harbour seals Phoca vitulina with at least $4(0.7 \%)$. Mackerel were never observed directly, but the presence of one or more gannets with $62(10.2 \%)$ bird groups may have been an indication that mackerel were present, as they are a well-known prey of this species (Nelson 2002). It is unlikely that mackerel were involved in bringing to the surface a very high proportion of the fish shoals on which the birds were feeding, however, as in this case a concentration of feeding aggregations would have been expected in areas where mackerel are known to occur. The best mackerel fishing grounds in the area are on and around Maxwell Bank to the south of the Isle of Eigg (Fig. 1; C. Dyer \& R. Dyer pers. comm.), and yet no spatial clustering of feeding aggregations in those locations was recorded.

One of the principal processes involved in maintaining mixed-species feeding aggregations is the maximization of foraging efficiency for individuals. Depending on the taxa concerned, this can involve mechanisms such as those described by the feeding efficiency theory, but also the beater or pirate theories (Diamond 1981). Different feeding strategies allow different seabird taxa to simultaneously exploit patchy food resources in accordance with the feeding efficiency theory. However, the interaction between Larus gulls and auks (but also kittiwakes) in these aggregations can most accurately be described by the pirate theory, with gulls taking advantage of and stealing prey concentrated by the auks, often causing feeding groups to break up (Camphuysen \& Webb 1999). In the present study, we have described a situation which stands in contrast to the widely accepted rule that seabirds profit from marine mammals in feeding aggregations involving both taxa. Our results indicate that the interaction between minke whales and auks is also best described by the pirate theory, with the whales stealing entire bait balls herded by auks. However, kittiwakes, in particular, profit from lunge-feeding whales in accordance with the beater theory, gaining access to scattered, injured or dead fish left immediately after a surface lunge by the whale. When feeding on a concentrated fish shoal driven to the surface by auks, on the other hand, Larus gulls often block access to the fish to the smaller kittiwakes by placing themselves on top of the bait ball (Camphuysen \& Webb 1999). This shows that a variety of mechanisms can be involved simultaneously in maintaining multi-species feeding groups. Interactions between different taxa can be dynamic, with the relative gain for some species changing according to the exact composition of the group. Multispecies feeding assemblages can therefore be maintained even if individuals of certain species or taxa experience temporary disadvantages by joining them.

Acknowledgements. P.A.'s PhD was financially supported by the Basler Stiftung für Biologische Forschung, the British Council and the Swiss Study Foundation. The fieldwork for the present study was funded by the National Geographic Society, Eleanor Dorsey Fund, Stiftung Dr. Joachim de Giacomi and Sea Watch Foundation. Underwater filming was conducted by M. I. Francis and C. Scott. We also thank R. Dyer, C. Swann, G. McCoy and all the other people who contributed to this project as skippers, volunteer field assistants or by providing logistical support.

\section{LITERATURE CITED}

Anderwald P (2009) Population genetics and behavioural ecology of North Atlantic minke whales (Balaenoptera acutorostrata). PhD thesis, University of Durham

Anderwald P, Evans PGH, Gygax L (2002) Relationship of minke whales (Balaenoptera acutorostrata), harbour porpoises (Phocoena phocoena) and feeding-groups of seabirds in the Inner Hebrides, Scotland. In: Evans PGH (ed) European Research on Cetaceans. Proc 16th Annual Conference ECS, Liège, Belgium, 7-11 Apr 2002. European Cetacean Society, Cambridge

Ballance LT, Pitman RL (1999) Foraging ecology of tropical seabirds. In: Adams NJ, Slotow RH (eds) Proc 22nd Int Ornithol Congr. BirdLife South Africa, Durban, p 2057-2071 Bearzi M, Saylan CA, Feenstra J (2009) Seabird observations 
during cetacean surveys in Santa Monica Bay, California. Bull South Calif Acad Sci 108:63-69

Begon M, Harper JL, Townsend CR (1986) Ecology: individuals, populations and communities. Blackwell Science, Oxford

Blix AS, Folkow LP (1995) Daily energy expenditure in free living minke whales. Acta Physiol Scand 153:61-66

Bräger S (1998) Feeding associations between white-fronted terns and Hector's dolphins in New Zealand. Condor 100: $560-562$

Brooke M (1990) The Manx shearwater. T. \& A. D. Poyser Academic Press, London

Bugoni L, Vooren CM (2004) Feeding ecology of the common tern Sterna hirundo in a wintering area in southern Brazil. Ibis 146:438-453

Camphuysen KCJ, Webb A (1999) Multi-species feeding associations in North Sea seabirds: jointly exploiting a patchy environment. Ardea 87:177-198

Carscadden JE, Montevecchi WA, Davoren GK, Nakashima BS (2002) Trophic relationships among capelin (Mallotus villosus) and seabirds in a changing ecosystem. ICES J Mar Sci 59:1027-1033

Clarke MR, Prince PR (1981) Cephalopod remains in regurgitations of black-browed and grey-headed albatrosses at South Georgia. Br Antarct Surv Bull 54:1-7

Clarke MR, Croxall JP, Prince PR (1981) Cephalopod remains in regurgitations of the wandering albatross Diomedea exulans L. at South Georgia. Br Antarct Surv Bull 54:9-21

Davoren GK, Montevecchi WA (2003) Signals from seabirds indicate changing biology of capelin stocks. Mar Ecol Prog Ser 258:253-261

De Silva SS (1973) Abundance, structure, growth and origin of inshore clupeid populations of the west coast of Scotland. J Exp Mar Biol Ecol 12:119-144

Diamond JM (1981) Mixed-species foraging groups. Nature 292:408-409

Duffy DC (1983) The foraging ecology of Peruvian seabirds. Auk 100:800-810

Evans PGH (1980) Cetaceans in British waters. Mammal Rev 10:1-52

Evans PGH (1982) Associations between seabirds and cetaceans: a review. Mammal Rev 12:187-206

Evans PGH (1990) European cetaceans and seabirds in an oceanographic context. Lutra 33:95-125

Gaston AJ (2004) Seabirds: a natural history. T. \& A. D. Poyser, London

Gaston AJ, Jones IL, Lewington I (1998) The auks. Oxford University Press, Oxford

Harrison CS (1979) The association of marine birds and feeding gray whales. Condor 81:93-95

Harrison NM, Whitehouse MJ, Heinemann D, Prince PA, Hunt GL, Veit RR (1991) Observations of multispecies seabird flocks around South Georgia. Auk 108:801-810

Hatchwell BJ (1991) The feeding ecology of young guillemots Uria aalge on Skomer Island, Wales. Ibis 133:153-161

> Hislop JRG, Harris MP, Smith JGM (1991) Variation in the

Editorial responsibility: John Piatt,

Anchorage, Alaska, USA calorific value and total energy content of the lesser sandeel (Ammodytes marinus) and other fish preyed on by seabirds. J Zool 224:501-517

Hoelzel AR, Dorsey EM, Stern SJ (1989) The foraging specializations of individual minke whales. Anim Behav 38: $786-794$

Hoffman W, Heinemann D, Wiens JA (1981) The ecology of seabird feeding flocks in Alaska. Auk 98:437-456

Lee AJ, Ramster JW (1981) Atlas of the seas around the British Isles. Ministry of Agriculture, Fisheries and Food (MAFF), Lowestoft

Martin AR (1986) Feeding association between dolphins and shearwaters around the Azores Islands. Can J Zool 64: $1372-1374$

Nelson B (2002) The Atlantic gannet, 2nd edn. Fenix Books, Great Yarmouth

Piatt JF, Nettleship DN (1985) Diving depths of four alcids. Auk 102:293-297

Pierotti R (1988a) Interactions between gulls and otariid pinnipeds: competition, commensalisms, and cooperation. In: Burger J (ed) Seabirds and other marine vertebrates: competition, predation and other interactions. Columbia University Press, New York, NY, p 213-239

Pierotti R (1988b) Associations between marine birds and mammals in the Northwest Atlantic Ocean. In: Burger J (ed) Seabirds and other marine vertebrates: competition, predation and other interactions. Columbia University Press, New York, NY, p 31-58

Pitman RL, Ballance LT (1992) Parkinson's petrel distribution and foraging ecology in the Eastern Pacific: aspects of an exclusive feeding relationship with dolphins. Condor 94:825-835

Rowntree VJ, McGuinness P, Marshall K, Payne R, Sironi M, Seger J (1998) Increased harassment of right whales (Eubalaena australis) by kelp gulls (Larus dominicanus) at Península Valdés, Argentina. Mar Mamm Sci 14:99-115

Sealy SG (1973) Interspecific feeding assemblages of marine birds off British Columbia. Auk 90:796-802

Shamoun-Baranes J, van Loon E (2006) Energetic influence on gull flight strategy selection. J Exp Biol 209:3489-3498

Simpson EH (1949) Measurement of diversity. Nature 163:688

Skøv H, Durinck J, Andell P (2000) Associations between wintering avian predators and schooling fish in the Skagerrak-Kattegat suggest reliance on predictable aggregations of herring Clupea harengus. J Avian Biol 31:135-143

Thomas PO (1988) Kelp gulls, Larus dominicanus, are parasitic on flesh of the right whale, Eubalaena australis. Ethology 79:89-103

> Vaughn RL, Würsig B, Shelton DS, Timm LL, Watson LA (2008) Dusky dolphins influence prey accessibility for seabirds in Admiralty Bay, New Zealand. J Mammal 89: 1051-1058

- Verheyden C (1993) Kelp gulls exploit food provided by active right whales. Colon Waterbirds 16:88-91

> Wanless S, Harris MP (1992) Activity budgets, diet and breeding success of kittiwakes Rissa tridactyla on the Isle of May. Bird Study 39:145-154

Submitted: April 12, 2010; Accepted: November 20, 2010

Proofs received from author(s): February 6, 2011 